\title{
The Influence of Managerial Ability of School Principals and The Climate of School Organizations on Teacher Performance During The Covid-19 Pandemic
}

\author{
Khuluqo, I. E \\ Universitas Muhammadiyah Prof. DR. HAMKA, Indonesia \\ e-mail:khuluqo99@gmail.com
}

Tenkahary, C. M

MTS Negeri 3 Tasikmalaya, Tasikmalaya, Indonesia e-mail: tenkahary78@yahoo.com

\section{A R T I C L E I N F O \\ Article history: \\ 25 December 2020 \\ Received in revised form \\ 01 January 2021 \\ Accepted 25 January 2021 \\ Available online 03 February 2021}

\section{Kata Kunci: \\ Handout Digital Interaktif, Hasil Pembelajaran \\ Keywords: \\ Managerial Ability, School \\ Climate, Teacher \\ Performance}

\begin{abstract}
A B S T R A K
Peran kepala sekolah sangat penting dalam mengoptimalkan kinerja guru di masa pandemi Covid-19. Selain itu, iklim organisasi sekolah yang kondusif mampu memberikan solusi atas permasalahan kinerja guru yang muncul di masa pandemi Covid-19. Penelitian ini bertujuan untuk menganalisis pengaruh Kemampuan Manajerial Kepala Sekolah dan Iklim Organisasi Sekolah terhadap Kinerja Guru Pada Masa Pandemi Covid-19. Jenis penelitian ini adalah penelitian kuantitatif. Metode penelitian yang digunakan adalah metode kuantitatif. Populasi dalam penelitian ini berjumlah 184 . Sampel dalam penelitian ini adalah 126 guru. Teknik yang digunakan untuk mengumpulkan data adalah wawancara dan observasi. Instrumen yang digunakan untuk mengumpulkan data adalah kuesioner. Hasil penelitian menunjukkan bahwa kemampuan manajerial kepala sekolah berpengaruh terhadap kinerja guru yang ditunjukkan oleh Fhitung $92.102(\mathrm{p}<0,05)$ dan memiliki keketatan yang kuat berdasarkan nilai koefisien korelasi sebesar 0,653 . Selanjutnya iklim organisasi sekolah berpengaruh terhadap kinerja guru yang ditunjukkan dengan Fhitung $126.784(\mathrm{p}<0,05)$ dan memiliki keketatan yang kuat berdasarkan koefisien korelasi sebesar 0,711 . Selain itu, kemampuan manajerial kepala sekolah dan iklim organisasi sekolah secara simultan
\end{abstract} berpengaruh terhadap kinerja guru berdasarkan nilai Fhitung 75,497 $(\mathrm{p}<0,05)$ dan memiliki keketatan yang kuat berdasarkan nilai R sebesar 0,742. Dapat disimpulkan bahwa kemampuan manajerial kepala sekolah dan iklim organisasi sekolah secara simultan berpengaruh terhadap kinerja guru di masa pandemi Covid-19.

\begin{abstract}
A B S T R A C T
The role of school principals is very important in optimizing teacher performance during the Covid-19 pandemic. In addition, a conducive school organizational climate is able to provide solutions to teacher performance problems that arise during the Covid-19 pandemic. This study aims to analyze the effect of Principal Managerial Ability and School Organizational Climate on Teacher Performance During the Covid-19 Pandemic. This type of research is quantitative research. The research method used is a quantitative method. The population in this study amounted to 184 . The sample in this study was 126 teachers. The technique used to collect data is interview and observation. The instrument used to collect data is a questionnaire. The results showed that the principal's managerial ability had an effect on teacher performance as indicated by the Fcount 92,102 ( $\mathrm{p}$ $<0.05$ ) and had a strong tightness based on the correlation coefficient value of 0.653 . Furthermore, the school organizational climate affects teacher performance as indicated by the Fcount $126,784(\mathrm{p}<0.05)$ and has a strong tightness based on the correlation coefficient of 0.711 . In addition, the principal's managerial ability and school organizational climate simultaneously affect teacher performance based on the Fcount $75.497(\mathrm{p}<0.05)$ and has a strong tightness based on the R value of 0.742 . It can be concluded that the principal's managerial ability and the school's organizational climate simultaneously affect teacher performance during the Covid-19 pandemic.
\end{abstract}

\section{Introduction}

During the Covid-19 pandemic, the learning process at school is carried out from home, either through distance learning or online. This is to prevent the spread of the virus (Batubara \& Batubara, 2020; Chang et al., 2020). One of the efforts made by the government to overcome the transmission of the Covid-19 disease is by making regulations on Large-Scale Social Restrictions in the context of accelerating the handling of the 2019 Corona Virus Disease (Covid-19). These regulations are large-scale social restrictions, namely schools and workplaces (Mona, 2020; Susilo et al., 2020). So that the learning process at school is carried out from home until the next notification. Learning that cannot be done at school so online learning is carried out. This learning 
provides a meaningful learning experience for students (Anugrahana, 2020; Santi, 2019). The problem that occurs today is that changes in the way of learning make it difficult for teachers to design quality online learning for students (Batubara \& Batubara, 2020; Maulana \& Hamidi, 2020). This causes students also have difficulty in learning online. Changes in the way of learning lead to a decrease in the quality of teacher performance. Currently, teachers are required to be able to adapt and use technology to support online learning (Albiladi, 2019; Wulandari, Sudatha, \& Simamora, 2020). With advances in technology will help teachers in teaching online. Teachers can use technology to deliver subject matter to students, such as creating learning media that can facilitate students to learn independently (Krisna, D, \& Abadi, 2013; Mirawati, 2015; Yusnia, 2019). Based on these problems, the teacher must improve the quality of performance so that learning objectives will be achieved even though learning is done online.

Performance refers to the level of achievement of tasks that make a person meet the requirements of the job. This reflects how well a person carries out the demands of a job (Junianto \& Wagiran, 2013; Sulaefi, 2017). Teacher performance is the most important part in improving the quality of education; Therefore, the assessment of co-working is something that needs to be taken seriously, especially by school principals and supervisors (Mudiyantun, 2019; Mustikeni, 2019). Performance is also the result of work achieved by a person in carrying out the tasks assigned to him based on ability, experience and seriousness as well. So that teacher performance is a condition that shows the ability of teachers to carry out their duties at school and illustrates the existence of an act that is displayed by the teacher in carrying out learning activities. Teacher performance will be supervised by the principal (Wahyudin, 2018; Yani, 2014). A school principal has a very important role in responding to the implementation of home learning during the Covid-19 pandemic. The principal is a functional teacher who is in charge of leading the place where the teaching and learning process takes place, or a place for interaction between teachers who give lessons and students who receive lessons. (Subagia, Yudana, \& Divayana, 2019; Wote \& Patalatu, 2019). The principal can make policies that support the implementation of learning at home so that quality learning can be accepted by students at home. However, not all principals have adequate managerial skills to respond to this, so that some principals have not been able to carry out the learning process from home properly. Among them are not planning learning from home, not providing supporting facilities for learning from home, not supervising learning from home and not evaluating learning from home. Whereas a school principal is required to have good managerial skills. The managerial ability referred to here is related to the ability to plan, organize, drive, and control (Muliartini, Natajaya, \& Sunu, 2019; Yusuf, 2012). So that the principal can lead and direct teachers to carry out learning from home during the Covid-19 pandemic.

The principal's managerial abilities include personality competencies, managerial abilities, entrepreneurial competencies, supervisory competencies, and social competencies (Putrayana, Agung, \& Sunu, 2018; Sugihartini, Agung, \& Dantes, 2018). The principal is the driving factor for realizing the vision, mission, achievements and goals of the school he leads to become a quality school (Kuswana, 2019). Principals are required to have managerial skills so that good ones can be role models for teachers and can bring schools to be of high quality. Skilled leaders envision future needs and empower others to share and properly implement that vision (Laksmi, Agung, \& Sudirman, 2019; Yayuk \& Sugiyono, 2019). Based on the description above, the managerial ability of the principal is the principal, besides being able to carry out the management process that refers to the management function, he is also required to understand and apply all the substance of educational activities. The end product of the interaction between groups of students in schools, teachers, and businessminded employees who work to achieve between the organizational (school) and individual dimensions. Products include values, social standards and social beliefs. In addition, the school organizational climate is the quality of the school environment that is continuously experienced by teachers, influences their behavior, and is based on collective perceptions (Hardiyanto, 2016). School organizational climate is defined as students' perceptions and feelings related to the social environment in the madrasa with basic dimensions originating from the school's organizational climate, namely ecology, environment, organization, and culture. (Prasetyo, 2018).

The school's organizational climate has dimensions that are developed from general dimensions, namely: relationship dimensions, dimensions of personal growth / development, dimensions of system change and improvement, and dimensions of the physical environment. The school's organizational climate can influence the behavior of members in the organization in achieving a specified set of goals (Wonodipho, 2019). Based on the above understanding, the school organizational climate is a characteristic of madrasas that distinguishes one madrasa from another, which affects the behavior of principals, teachers, and students. Psychologically, the school's organizational climate is a feeling felt by teachers, students of a madrasa. The school's organizational climate will affect the behavior patterns of members of the madrasa organization which is then used as the basis for translating the situation and becomes a source of pressure for leadership activities. Research conducted by Nugraha (2017) states that job satisfaction consists of job characteristics, salary, supervisor, co-workers, and working conditions. The organizational climate in the school is not good in terms of all aspects and teacher job satisfaction is still low in all aspects. Research conducted by Prasetyo (2018) stated that there was a significant positive correlation between perceptions of school climate and the subjective well- 
being of students at school. It can be concluded that organizational climate has an effect on teacher performance. This study aims to analyze the effect of Principal Managerial Ability and School Organizational Climate on Teacher Performance During the Covid-19 Pandemic. It is hoped that the managerial ability of the principal and a good school organizational climate will affect teacher performance during the COVID-19 pandemic.

\section{Method}

This type of research is quantitative research. The approach used in this study is a quantitative approach, through correlational research or looking for the effect of principal managerial capabilities (X1) and school organizational climate (X2) on teacher performance ( $\hat{Y})$ during the Covid-19 pandemic. in a private Madrasah Tsanawiyah in Parung District, Bogor Regency. The research method used is a quantitative method. The population in this study amounted to 184. The sample in this study was 126 teachers. The technique used to collect data is interview and observation. The instrument used to collect data is a questionnaire. The questionnaire used was based on 5 Likert scales. Questionnaires in the form of questions were distributed to respondents in private Madrasah Tsanawiyah, Parung sub-district, Bogor district, which consisted of six schools, namely: MTs. Nurul Hidayah, MTs. Darunna'im YAPIA, MTs. Sirajul Falah, MTs. Darul Muttaqin, MTs. AlAthfal and MTs. Darussalam. This study uses the Slovin formula to take the sample

\section{Result and Discussion}

From the questionnaire that has been given to 126 respondents with 14 question items about teacher performance during the Covid-19 pandemic, the following results were obtained: highest score $=70$, lowest score $=44$, average $=59.99$, standard deviation $=6,297$, variance $=39,656$, range $=26$, number of classes $=8$, class interval $=4$, mode $=55$, and median $=60$. From the questionnaire that has been given to 126 respondents with 11 question items regarding the managerial ability of the principal with the following results: highest score $=55.00$, lowest score $=32.00$, mean $=48.59$, standard deviation $=4,969$, variance $=24,692$, range $=23$, number of classes $=8$, class interval $=3$, mode $=50$, and median $=50$. The Climate of School Organization (X2). The first hypothesis in this study is "There is a significant and positive effect of the principal's managerial skills on teacher performance". The hypotheses were analyzed using linear regression equations. The results obtained significant correlation coefficient obtained $\mathrm{r}=0.653$ and the value of tcount $=9.597>\mathrm{t}$-table $=1.980$ and $\mathrm{p}$ value $=0.000<0.05$. This means that there is a very significant positive effect between the principal's managerial ability variable $(\mathrm{X} 1)$ and the teacher's performance variable $(\hat{\mathrm{Y}})$. The results are shown in the following table 1.

Tabel 1. Principal's Managerial Ability Variable (X1) And The Teacher's Performance Variable (Ŷ)

\begin{tabular}{|c|c|c|c|c|c|c|}
\hline \multicolumn{7}{|c|}{ Coefficients $^{\mathrm{a}}$} \\
\hline \multirow{2}{*}{\multicolumn{2}{|c|}{ Model }} & \multicolumn{2}{|c|}{$\begin{array}{l}\text { Unstandardized } \\
\text { Coefficients }\end{array}$} & \multirow{2}{*}{$\begin{array}{c}\begin{array}{c}\text { Standardized } \\
\text { Coefficients }\end{array} \\
\text { Beta } \\
\end{array}$} & \multirow[t]{2}{*}{$\mathbf{t}$} & \multirow[t]{2}{*}{ Sig. } \\
\hline & & B & Std. Error & & & \\
\hline \multirow[b]{2}{*}{1} & (Constant) & 19,794 & 4,210 & & 4,701 & ,000 \\
\hline & $\begin{array}{l}\text { Manajerial Ability of The } \\
\text { School Principal }\end{array}$ & ,827 & ,086 & ,653 & 9,597 & ,000 \\
\hline
\end{tabular}

a. Dependent Variable: teacher performance

The second hypothesis in this study is "There is a significant influence of school organizational climate on teacher performance". The hypotheses were analyzed using linear regression equations. The correlation coefficient significance results obtained $\mathrm{r}=0.711$ and tcount $=11.260>\mathrm{F}_{-}$table $=1.980$ and $\mathrm{p}$ value $=0.000$ $<0.05$. This means that there is a significant positive effect between the school organizational climate variable (X2) and the teacher performance variable $(\hat{Y})$. The results are shown in the following table 2 . The third hypothesis in this study is "There is a significant effect of the managerial capability of the principal and the school's organizational climate simultaneously on teacher performance". The hypotheses were analyzed using multiple linear regression equations. From the total regression results, the Fcount value of 26.86 is greater than the Ftable value (3.07). This means that the teacher's performance is simultaneously significantly influenced by the independent variables. The results are shown in the following table 3 
Tabel 2. Effect Between The School Organizational Climate Variable (X2) And The Teacher Performance Variable $(\hat{\mathrm{Y}})$

\begin{tabular}{|c|c|c|c|c|c|c|}
\hline \multicolumn{7}{|c|}{ Coefficients $^{\mathbf{a}}$} \\
\hline \multirow{2}{*}{\multicolumn{2}{|c|}{ Model }} & \multicolumn{2}{|c|}{$\begin{array}{l}\text { Unstandardized } \\
\text { Coefficients }\end{array}$} & \multirow{2}{*}{$\begin{array}{c}\begin{array}{c}\text { Standardized } \\
\text { Coefficients }\end{array} \\
\text { Beta } \\
\end{array}$} & \multirow[t]{2}{*}{$\mathbf{t}$} & \multirow[t]{2}{*}{ Sig. } \\
\hline & & B & Std. Error & & & \\
\hline \multirow[t]{2}{*}{1} & (Constant) & 17,366 & 3,806 & & 4,562 &, 000 \\
\hline & $\begin{array}{l}\text { The Climate of School } \\
\text { Organization }\end{array}$ & ,854 & ,076 & $=, 711$ & 11,260 &, 000 \\
\hline
\end{tabular}

Tabel 3. Eacher's Performance Is Simultaneously Significantly Influenced By The Independent Variables

\begin{tabular}{llrrrrr}
\hline \multicolumn{7}{c}{ ANOVA $^{\text {a }}$} \\
\hline Model & & Sum of Squares & df & Mean Square & F & Sig. \\
\hline \multirow{2}{*}{1} & Regression & 2731,717 & 2 & 1365,859 & 75,497 &, $000^{\mathrm{b}}$ \\
& Residual & 2225,275 & 123 & 18,092 & & \\
\hline & Total & 4956,992 & 125 & & & \\
\hline
\end{tabular}

a. Dependent Variable: teacher performance

b. Predictors: (Constant), The Climate of School Organization, Manajerial Ability of The School Principal

The fourth hypothesis in this study is "There is a relationship between the principal's managerial ability and the school's organizational climate together on teacher performance". The hypotheses were analyzed using multiple correlation analysis. It is known that the Sif.F Change value is 0.000 and is less than 0.05 . This means that simultaneously the principal's managerial ability and the school's organizational climate have an effect on the teacher's performance during the Covid-19 pandemic. In addition, the value of $\mathrm{R}$ which is the value of the correlation coefficient is 0.742 . This means that the level of correlation between the managerial ability of principals and the school's co-organizational climate with teacher performance during the Covid-19 pandemic is strong. The results are shown in the following table 4.

Tabel 4. correlation between the managerial ability of principals and the school's co-organizational climate

\begin{tabular}{|c|c|c|c|c|c|c|c|c|}
\hline \multicolumn{9}{|c|}{ Model Summary } \\
\hline \multirow[t]{2}{*}{ Model } & \multirow[t]{2}{*}{$\mathbf{R}$} & \multirow{2}{*}{$\begin{array}{c}\mathbf{R} \\
\text { Square }\end{array}$} & \multirow{2}{*}{$\begin{array}{l}\text { Adjusted R } \\
\text { Square }\end{array}$} & \multirow{2}{*}{$\begin{array}{c}\text { Std. Error } \\
\text { of the } \\
\text { Estimate }\end{array}$} & \multicolumn{4}{|c|}{$\begin{array}{l}\text { Change Statistics } \\
\end{array}$} \\
\hline & & & & & $\begin{array}{l}\text { R Square } \\
\text { Change }\end{array}$ & $\begin{array}{c}\text { F } \\
\text { Change }\end{array}$ & df1 df2 & $\begin{array}{c}\text { Sig. F } \\
\text { Change }\end{array}$ \\
\hline 1 &, $742^{\mathrm{a}}$ &, 551 &, 544 & 4,253 &, 551 & 75,497 & 123 &, 000 \\
\hline
\end{tabular}

The results showed that there was an influence of the principal's managerial ability on teacher performance. This can be seen from the value of Fcount $=92.102>$ Ftable $=3.07$ and the value of $p$ value $=$ $0.000<0.05$. Meanwhile, the tightness of the principal's managerial ability with the teacher's performance can be seen from the correlation coefficient value of 0.653 . The influence of the principal's managerial ability on teacher performance shows that it is very important for principals to have managerial skills such as directing, developing others, cooperation, and being able to be a good leader. (Cahyaningrum, 2020; Mukhtar, 2015). The principal's human skills include 1) the ability to understand human behavior with a cooperative process, 2) the ability to understand the hearts, attitudes and motives of others, why they say and behave, 3) the ability to communicate effectively, 4) the ability to create effective cooperation., cooperative, practical and diplomatic and 5) able to behave in an acceptable manner (Laksmi et al., 2019; Yayuk \& Sugiyono, 2019). Teacher performance during the Covid-19 pandemic desperately needs the principal's strategic policy to plan, organize, mobilize, and control the learning process, especially in managing distance learning activities from home. So that school principals can improve the quality of teacher performance as a basis for improving the quality of education services during the Covid-19 pandemic(Dewi, 2020; Mustikaningrum, Pramusinta, Ayu, \& Umar, 2020). The head of the madrasa is responsible for maintaining and motivating teachers, students, and school administrative staff to be willing and able to implement the laws and regulations that apply in the school. This is the point that the principal must be able to carry out the role of the principal and his abilities in the field of madrasa management. 
The results of the research and hypothesis testing showed the value of Fcount $=126.784>$ Ftable $=3.07$ and $\mathrm{p}$ value $=0.000<0.05$ so that the research hypothesis was accepted. Meanwhile, the tight relationship between school organizational climate and teacher performance can be seen from the correlation coefficient value of 0.711 . These results indicate the effect of school organizational climate on teacher performance. The results of this study indicate that the quality climate and good school administration contribute to improving teacher performance. Teacher performance in madrasas is strongly influenced by the quality of teacher interaction with the madrasa environment (Mukhtar, 2015; Sari, 2019). Good interaction between fellow teachers, between teachers and principals, between teachers and education personnel, as well as between teachers and students. Openness in a climate is positively related to the openness of authentic teacher and principal behavior (Nugraha, 2017; Nurhasnawati \& Subhan, 2018). The open school climate has a positive relationship with the open and authentic behavior of teachers and principals. Moreover, the school organizational climate during the Covid-19 pandemic has a different atmosphere from the school organizational climate in normal conditions. The school organizational climate must be maintained conducive so that it can have a good influence on teacher performance, especially during the Covid-19 pandemic.

The results of the research and hypothesis testing show that Fcount $=26.86$ is greater than Ftable $=$ 3.07 , so the research hypothesis is accepted. In other words, there is a joint influence of the principal's managerial ability and school organizational climate on teacher performance during the Covid-19 pandemic. In addition, the correlation coefficient of the independent variable, the managerial ability of the principal and the school's organizational climate together on the dependent variable of teacher performance is 0.742 . This means that the level of correlation between the managerial ability of the principal and the school's organizational climate simultaneously with the performance of teachers in the Covid-19 pandemic is strong. So it can be concluded that there is a strong influence between the managerial capability of the principal and the school organizational climate together on the performance of teachers during the Covid-19 pandemic.

From the results of the research above, it can also be seen that the independent variable School Organizational Climate has a more dominant influence on the dependent variable on Teacher Performance because it has a beta coefficient value of 0.499 compared to the Principal Managerial beta coefficient value. Ability 0.311. So it can be concluded that the role of the principal and the entire teacher council must work together to create a good and quality school organizational climate so that it can have a major impact on the performance of good and quality teachers. This focuses on the central role of school principals in activities and maintaining the conduciveness of teaching and learning activities during the Covid-19 pandemic. The principal as the highest leader in the school environment must be able to develop the school community, especially teachers and employees (Ramadoni, Kusmintardjo, \& Arifin, 2016; Widyantara, 2019; Wijania, 2017). The development of others is related to the ability to take effective action to improve the skills and talents of others.

\section{Conclusion}

The managerial ability of school principals affects teacher performance during the Covid-19 pandemic. In addition, the school organizational climate affects teacher performance during the Covid-19 pandemic. The managerial ability of the principal and the school's organizational climate simultaneously affect the performance of teachers at the Private Tsanawiyah Madrasah in Parung District, Bogor During the Covid-19 Pandemic.

\section{References}

Albiladi, K. (2019). Blended Learning in English Teaching and Learning: A Review of the Current Literature. Journal of Language Teaching and Research, 10(2), 232-238. https://doi.org/http://dx.doi.org/10.17507/jltr.1002.03.

Anugrahana, A. (2020). Hambatan, Solusi dan Harapan : Pembelajaran Daring Selama Masa Pandemi Covid-19 Oleh Guru Sekolah Dasar. Scholaria: Jurnal Pendidikan Dan Kebudayaan, 10(3), 282-289.

Batubara, H. H., \& Batubara, D. S. (2020). Penggunaan Video Tutorial Untuk Mendukung Pembelajaran Daring Di Masa Pandemi Virus Corona. Muallimuna: Jurnal Madrasah Ibtidaiyah, 5(2), 21. https://doi.org/10.31602/muallimuna.v5i2.2950.

Cahyaningrum, R. (2020). Kontribusi Kemampuan Manajerial Kepala Sekolah, Motivasi Guru, dan Lingkungan Kerja Terhadap Kinerja Guru Sekolah Dasar. Media Manajemen Pendidikan, 3(1), 100. https://doi.org/10.30738/mmp.v3i1.4633.

Chang, T. Y., Hong, G., Paganelli, C., Phantumvanit, P., Chang, W. J., Shieh, Y. S., \& Hsu, M. L. (2020). Innovation of dental education during COVID-19 pandemic. Journal of Dental Sciences, 1(155). https://doi.org/10.1016/j.jds.2020.07.011.

Dewi, W. A. F. (2020). Dampak Covid-19 Terhadap Implementasi Pembelajaran Daring Di Sekolah Dasar. Jurnal Ilmu Pendidikan, 2(1). https://doi.org/https://doi.org/10.31004/edukatif.vi1.89. 
Hardiyanto. (2016). Teori Dan Pengembangan Iklim Kelas Dan Iklim Sekolah (KESATU). Jakarta: KENCANA.

Junianto, D., \& Wagiran, W. (2013). Pengaruh kinerja mengajar guru, keterlibatan orang tua, aktualisasi diri dan motivasi berprestasi terhadap prestasi. Jurnal Pendidikan Vokasi, 3(3), 307-319. https://doi.org/10.21831/jpv.v3i3.1845.

Krisna, N. L. P. G., D, I. W. R., \& Abadi, I. B. G. S. (2013). Pengaruh Model Pembelajaran Kuantum berbantuan Media Video Kontekstual terhadap Hasil Belajar IPA Siswa di SDN 2 Dangin Puri. MIMBAR PGSD Undiksha, 1(1). https://doi.org/http://dx.doi.org/10.23887/jjpgsd.v1i1.1261.

Kuswana, H. (2019). The Effect Of Managerial Capabilities Of Principal Toward School Quality In Vocational High School. Jurnal Kepemimpinan Pendidikan, $2(1)$. https://doi.org/https://doi.org/10.22236/jkpuhamka.v2i1.3805.

Laksmi, N. L. P. S., Agung, A. A. G., \& Sudirman. (2019). Hubungan Kepemimpinan Pelayan, Kompetensi Manajerial Kepala Sekolah, Budaya Organisasi, dan Motivasi Kerja Dengan Kinerja Guru di Gugus PAUD Tunjung Kecamatan Denpasar Utara. Jurnal Administrasi Pendidikan Indonesia, 10(2), 148156. https://doi.org/10.23887/japi.v10i2.2802.

Maulana, H. A., \& Hamidi, M. (2020). Persepsi Mahasiswa terhadap Pembelajaran Daring pada Mata Kuliah Praktik di Pendidikan Vokasi. Equilibrium: Jurnal Pendidikan, 8(2), 224-231. https://doi.org/10.26618/equilibrium.v8i2.3443.

Mirawati, I. (2015). Media Konsultasi Online Sebagai Alternatif Upaya Penanganan Masalah Remaja. EDULIB: Journal Of Library And Information Science, $\quad$ 5(1). https://doi.org/https://doi.org/10.17509/edulib.v5i1.2306.

Mona, N. (2020). Konsep Isolasi Dalam Jaringan Sosial Untuk Meminimalisasi Efek Contagious (Kasus Penyebaran Virus Corona Di Indonesia). Jurnal Sosial Humaniora Terapan, 2(2). https://doi.org/https://doi.org/10.7454/jsht.v2i2.86.

Mudiyantun, Y. (2019). The Investigation Of Situational Leadership, And Work Motivation On Kindergarden Teacher Performance. Jurnal Kepemimpinan Pendidikan, 2(1). https://doi.org/https://doi.org/10.22236/jkpuhamka.v2i1.3814.

Mukhtar. (2015). Strategi Kepala Sekolah Dalam Meningkatkan Kinerja Guru Pada Smp Negeri Di Kecamatan Masjid Raya Kabupaten Aceh Besar. Jurnal Magister Administrasi Pendidikan, 3(3). Retrieved from http://www.jurnal.unsyiah.ac.id/JAP/article/view/2873/2734.

Muliartini, Natajaya, \& Sunu. (2019). Kontribusi Kepemimpinan Kepala Sekolah, Etos Kerja, Kepuasan Kerja, dan Budaya Organisasi Sekolah Terhadap Kinerja Guru di SMKN 2 Singaraja. Jurnal Administrasi Pendidikan Indonesia, 10(1), 13-23. https://doi.org/10.23887/japi.v10i1.2786.

Mustikaningrum, G., Pramusinta, L., Ayu, S., \& Umar, M. (2020). Implementasi Pendidikan Karakter Terintegrasi Kurikulum Dan Metode Pembelajaran Pada Masa Pandemi Covid-19. AULADUNA: Jurnal Pendidikan Dasar Islam, $\quad 7(2), \quad 154-164$. https://doi.org/https://doi.org/10.24252/10.24252/auladuna.v7i2a5.2020.

Mustikeni. (2019). Peningkatan Kinerja Guru melalui Supervisi Edukatif Kolaboratif di SDN 2 Setanggor. Jurnal Edukasi Dan Sains, 1(2). Retrieved from https://ejournal.stitpn.ac.id/index.php/edisi/article/view/414.

Nugraha, M. F. (2017). Iklim Organisasi dan Kepuasan Kerja Guru di Sekolah Singosari Delitua. Jurnal Diversita Available, 3(1), 67-74. https://doi.org/http://dx.doi.org/10.31289/diversita.v5i1.2402.

Nurhasnawati \& Subhan, M. (2018). Pengaruh Antara Iklim Organisasi dan Kepuasan Kerja Dengan Organizational Citizenship Behavior Pada Guru MIN Se Kota Pekanbaru. Journal of Materials Processing Techno, 1(1), 1-8. https://doi.org/http://dx.doi.org/10.24014/ijiem.v1i2.6649.

Prasetyo, R. A. B. (2018). Persepsi Iklim Sekolah dan Kesejahteraan Subjektif Siswa di Sekolah. Jurnal Psikologi Teori Dan Terapan, 8(2). https://doi.org/https://doi.org/10.26740/jptt.v8n2.p133-144.

Putrayana, G. K., Agung, A. A. G., \& Sunu, I. G. K. A. (2018). Analisis Determinasi Gaya Gaya Kepemimpinan Kepala Sekolah, Manajemen Mutu, Lingkungan Kerja dan Komitmen Kerja Terhadap Kepuasan Kerja Guru SMA Negeri 1 Mengwi. Jurnal Administrasi Pendidikan Indonesia, 9(1), 77-87.

Ramadoni, Kusmintardjo, \& Arifin. (2016). Kepemimpinan Kepala Sekolah Dalam Upaya Peningkatan Kinerja Guru (Studi Multi Kasus Di Paud Islam Sabilillah Dan SDN Tanjungsari 1 Kabupaten Sidoarjo. Jurnal Pendidikan, 1(8). https://doi.org/http://dx.doi.org/10.17977/jp.v1i8.6620.

Santi, I. G. A. D. P. (2019). Pengaruh Model Pembelajaran Berbasis Masalah Terhadap Motivasi Berprestasi Dan Keterampilan Metakognisi. Jurnal Matematika, Sains, Dan Pembelajarannya (Online), 13. https://doi.org/http://dx.doi.org/10.23887/wms.v13i2.15915.

Sari, H. P. (2019). Pengaruh Kompetensi, Motivasi Kerja Dan Insentif Terhadap Kinerja Guru SMA. Perspektif Imu Pendidikan., 33(1). https://doi.org/https://doi.org/10.21009/PIP.331.8.

Subagia, N. K. T. F., Yudana, M., \& Divayana, D. G. H. (2019). Kontribusi Supervisi Klinis Kepala Sekolah , Motivasi Kerja, Iklim Kerja dan Tunjangan Profesi Terhadap Kepuasan Kerja Guru TK di Kecamatan 
Kuta Utara. Jurnal Administrasi Pendidikan Indonesia, 10(2), 101-110. https://doi.org/https://doi.org/10.23887/japi.v10i2.2796.

Sugihartini, N. M., Agung, A. A. G., \& Dantes, K. R. (2018). Kontribusi Implementasi Menejemen Sekolah Berbasis Nilai-Nilai Kearifan Lokal Tri Hita Karana, Kepemimpinan Pelayan Kepala Sekolah dan Kepuasan Kerja Terhadap Komitmen Organisasional Guru di SMP Negeri Kota Singaraja Buleleng. Jurnal Administrasi Pendidikan Indonesia, 9(2), 111-120. https://doi.org/10.23887/japi.v9i2.2776.

Sulaefi. (2017). Pengaruh Pelatihan dan Pengembangan Terhadap Disiplin Kerja dan Kinerja Karyawan. Jurnal Manajemen Kewirausahaan, $5(1) . \quad$ Retrieved from http://jurnal.unmer.ac.id/index.php/jmdk/article/view/1212.

Susilo, Rumende, Pitoyo, Santoso, Yulianti, Herikurniawan, \& Sinto. (2020). Coronavirus Disease 2019: Tinjauan Literatur Terkini Coronavirus Disease 2019: Review of Current Literatures. Jurnal Penyakit Dalam Indonesia, 7(1). https://doi.org/http://dx.doi.org/10.7454/jpdi.v7i1.415.

Wahyudin, W. (2018). Optimalisasi Peran Kepala Sekolah dalam Implementasi Kurikulum 2013. Jurnal Kependidikan, 6(2), 249-265. https://doi.org/10.24090/jk.v6i2.1932.

Widyantara, S. (2019). Kontribusi Motivasi Kerja, Kepemimpinan Kepala Sekolah, dan Kompensasi Terhadap Kepuasan Kerja Guru. Media Manajemen Pendidikan, 2(1), 135. https://doi.org/10.30738/mmp.v2i1.3661.

Wijania, I. W. (2017). Kontribusi Kepemimpinan Pelayan Kepala Sekolah, Motivasi Kerja dan Disiplin Kerja Terhadap Kinerja Guru. Jurnal Ilmiah Pendidikan Dan Pembelajaran, 1(4), 176-184.

Wonodipho, A. R. (2019). Establishing Interpersonal Communication And Organizational Climate To Improve Work Motivation. Jurnal Kepemimpinan Pendidikan, $2(1)$. https://doi.org/https://doi.org/10.22236/jkpuhamka.v2i1.3816.

Wote, A. Y. V., \& Patalatu, J. S. (2019). Pengaruh Gaya Kepemimpinan Transformasional dan Kepuasan Kerja terhadap Kinerja Guru Sekolah Dasar. Jurnal Ilmiah Sekolah Dasar, 3(4), 465. https://doi.org/10.23887/jisd.v3i4.21782.

Wulandari, Sudatha, \& Simamora. (2020). Pengembangan Pembelajaran Blended Pada Mata Kuliah Ahara Yoga Semester II di IHDN Denpasar. Jurnal Edutech Undiksha, 8(1), 1-15. https://doi.org/http://dx.doi.org/10.23887/jeu.v8i1.26459.

Yani, H. (2014). Peran Kepemimpinan Kepala Sekolah dalam Pembiasaan Beragama dan Berbudi Pekerti Siswa. Mudarrisa: Jurnal Kajian Pendidikan https://doi.org/https://doi.org/10.18326/mdr.v6i2.168-193.

Yayuk, S., \& Sugiyono, S. (2019). Pengaruh kepemimpinan kepala sekolah dan biaya pendidikan terhadap kualitas proses belajar mengajar dan dampaknya dengan kompetensi lulusan SMK di kabupaten Gunungkidul. Jurnal Akuntabilitas Manajemen Pendidikan, 7(1), 84-96. https://doi.org/10.21831/amp.v7i1.23758.

Yusnia, Y. (2019). Penggunaan Media Video Scribe Dalam Pembelajaran Literasi Sains Untuk Mahasiswa PGPAUD. Cakrawala Dini: Jurnal Pendidikan Anak Usia Dini, 10(1), 71-75. https://doi.org/https://doi.org/10.17509/cd.v10i1.17436.

Yusuf, M. (2012). Kinerja Kepala Sekolah dan Guru dalam Mengimplementasikan Pendidikan Inklusif. Jurnal Pendidikan Dan Kebudayaan, 18(4). https://doi.org/https://doi.org/10.24832/jpnk.v18i4.96. 